\section{An Alternative Earth: COMMENT}

\author{
Andrew Glikson \\ Research School of Earth Science, Australian National University, \\ Canberra, A.C.T.0200, Australia, Andrew.glikson@anu.edu.au
}

I wish to congratulate Warren Hamilton (2003) on his insights into early terrestrial evolution. Hamilton (2003) perceives Archaean crustal regimes that are fundamentally distinct from MesozoicCenozoic circum-Pacific belts. I thoroughly concur-in over 35 years work in early Precambrian terrains I have not yet come across ophiolite-mélange thrust assemblages such as are diagnostic of accretional wedges. Was the early Earth, as Hamilton (2003) suggests, dominated by a thin geothermally active sial crust, possibly incorporating remnant signatures of the so-called Late Heavy Bombardment?

Hamilton (2003) regards the 4.4-3.5 Ga time span as an "Era of nearly global felsic crust, too hot and mobile to stand as continents" (p. 11), stating "Archean mafic and ultramafic volcanic rocks are known to overlie only ancient felsic basement ... containing abundant small to huge enclaves of ultramafic, mafic, and anorthositic rocks" (p. 5), and "Volcanic and sedimentary 'greenstone belt' assemblages were deposited after ca. $3.5 \mathrm{Ga}$ (possibly $3.8 \mathrm{Ga}$ ) in some cratons-tobe and ca. 3.0 Ga in others on TTG basement"' (p. 6) (TTG-tonalitetrondhjemite-granodiorite assemblages). Hamilton's (2003) reasons include: (a) presence of the 4.4-3.8 Ga-old zircon xenocrysts in early Archaean granitoids, volcanic and sedimentary sequences; (b) $\mathrm{Pb}-\mathrm{Pb}$ evidence for pre-4.0 Ga ("Hadean") felsic rocks (Kamber et al., 2003), and (c) seismic reflection evidence for mid-crustal sial located below crustal levels dominated by Archean greenstone belts (Goleby et al., 2002). Whether an early regional to global sial existed, however, is open to the following questions.

First, an early sialic crust does not follow from the zircon evidence. The high survivability of zircon grains, as contrasted with difficulties in dating the mantle-derivation ages of mafic and ultramafic crustal materials, results in a marked methodological bias in favor of early felsic materials. By contrast, the isotopic age records of mafic and ultramafic rocks are less well preserved, for example U-Pb baddeleyite ages hardly survive in the metamorphosed volcanic enclaves which abound in the Archean gneisses.

Second, on an Earth dominated by small-scale convection systems and small-scale blocks, consistent with the structural pattern of granitegreenstone terrains, zircons of pre-greenstone ages do not necessarily represent an underlying sial. Such zircons may have been shed into sima- or sial-founded depositional basins (later deformed into greenstone belts) from older proximal and fringing sialic blocks, for example in rift-type tectonic settings. An example is the 3.26-3.24 Ga-old Strelley greenstone belt downfaulted between older 3.49-3.42 Ga terrains, Pilbara Craton, Western Australia (Van Kranendonk et al., 2002). Locally, the Strelley supracrustals unconformably overlap the older terrain, which does not however mean the latter formed a continuous basement beneath the Strelley greenstones. Yet older simatic crustal remnants may be represented by the 3.55-3.43 Ga-old Cooterunah, Warrawoona, and lower Onverwacht mafic-ultramafic volcanic groups, which contain older zircons and $\mathrm{Sm}-\mathrm{Nd}$ signatures originally identified by Hamilton et al. (1981). The older zircons may have been shed from neighboring fault-bounded ca. 3.7-3.6 Ga gneiss terrains, such as the Warrawagine gneiss (Van Kranendonk et al., 2002) and Swaziland gneiss (Kröner et al., 1991). These gneiss blocks do not suggest a subgreenstones sial more than, for example, does the Lord Howe continental rise suggest a felsic crust beneath the Tasman Sea, or do modern zircon-bearing Red Sea sediments suggest an underlying continental crust beneath the Red Sea rift.
Third, no sub-greenstones sialic basement is required by seismic mid-crustal sial zones in Archaean terrains in Western Australia (Goleby et al., 2002). Here, major subhorizontal shears, which detach highlevel supracrustal (greenstone) zones from low-level sial crustal zones, preclude identification of the original field and age relations between these terrains.

A global early Archean sialic crust, be it thin and geothermally active, can not be reconciled with the geochemistry and isotopic parameters of the Archean TTG suite which dominates granite-greenstone terrains (Glikson, 1979). The TTG suite implies two-stage mantle melting processes, namely partial melting of mafic crust, rather than recycling of sial. On a geothermally active Archean Earth two-stage mantle melting processes do not necessarily imply a plate tectonic regime, as similar petrogenetic processes could occur, for example, in subsiding sima-founded rift zones. Recycling and anatexis of early sial would inevitably give rise to fractionated large ion lithosphere element-rich granitoids, such as only form a late and relatively minor component of Archean batholiths in greenstone-granite terrains (Glikson, 1979). The low initial ${ }^{87} \mathrm{Sr} /{ }^{86} \mathrm{Sr}$ ratios and $\mathrm{Sm}-\mathrm{Nd}$ indices of Archean granitoids constrain the intervals between derivation from mantle-type materials and final crystallization in batholiths (McCulloch and Bennett, 1994).

Hamilton (2003) suggests early Archean gneisses may contain components derived from impact melt sheets formed during heavy bombardment as late as $3.9 \mathrm{Ga}$. This tantalizing possibility is yet to be tested by studies of platinum group elements and $\mathrm{Cr}$ isotopes of early gneisses. Could a large part of the zircon xenocrysts population have been derived from impact-related anorthositic crustal components? Hamilton's (2003) statement: "Huge bolides hit the Moon as late as $3.9 \mathrm{Ga}$, which more likely dates the tail end of main accretion than a late bombardment" (p. 6) is difficult to reconcile with the apparent scarcity of pre-4.0 Ga impact ejecta in the lunar highlands (Ryder, 1990). Further, the terrestrial impact evidence indicates that the socalled "Late Heavy Bombardment" did not constitute a "tail end," as major asteroid clusters are recorded ca. 3.47 Ga and 3.24 Ga (Lowe et al., 2003). The mafic composition of ejecta and spherule condensates (microkrystites) studied to date requires that these impacts, as well as $2.63 \mathrm{Ga}$ and $2.49 \mathrm{Ga}$ impacts (Simonson et al., 1998), formed craters hundreds of kilometers across in simatic/oceanic crustal regions of the Archean Earth.

A first order observation with which any early crustal model needs to contend is the origin of the marked episodicity of volcanic and plutonic events, for example in the Pilbara Craton (Glikson, 2001; Van Kranendonk et al., 2002). Figure 1 portrays this episodicity in the Pilbara Craton as revealed by the frequency of $\mathrm{U}-\mathrm{Pb}$ zircon dates, collated by Van Kranendonk et al. (2002). This episodicity may reflect purely internal mantle-crust dynamics or/and the triggering of mantle/crust melting events by episodic impacts. A major asteroid impact cluster dated as ca. $3.24 \mathrm{Ga}$ closely coincides with the abrupt change from the predominantly mafic-ultramafic volcanic Onverwacht Group to felsic volcanic-turbidite assemblages of the Fig Tree Group (Lowe et al., 2003). Whereas no ca. $3.24 \mathrm{Ga}$ impact fallout units were detected to date in the Pilbara Craton, this period is marked by a similar transition from mafic-ultramafic crust to olistostrome, turbidite, felsic volcanics and banded iron formation, accompanied by extensive major volcanic and plutonic activity (SVG in Fig. 1) (Van Kranendonk et al., 2002).

That the rapidly growing Archean databases do not appear to constrain an ever increasing diversity of early crustal models hints at fundamental methodological impasse in Archaean research. Applying Ockham's razor principle, the rocks need to be allowed to "speak for themselves," free of uniformitarian assumptions. Major unknowns remain. It is thanks to scientists like Warren Hamilton that the understanding of crustal evolution is growing. 


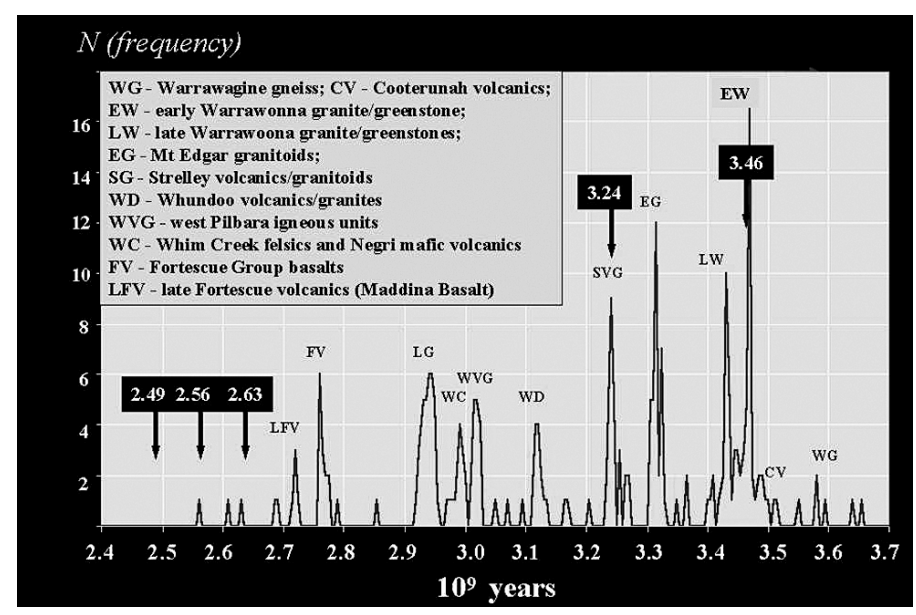

Figure 1. U-Pb zircon isotopic age frequency plot for igneous events in the Pilbara Craton, Western Australia. Data cited from Van Kranendonk et al. (2002). Arrows indicate ages of isotopically dated asteroid impact fallout units in the Pilbara and Kaapvaal cratons (Glikson, 2001).

\section{ACKNOWLEDGMENTS}

I thank Warren Hamilton for stimulating discussions and written communications, Arthur Hickman, and Martin Van Kranendonk for comments on this discussion, and Keith Howard for helpful comments.

\section{REFERENCES CITED}

Glikson, A.Y., 1979, Early Precambrian tonalite-trondhjemite sialic nuclei: Earth Science Reviews, v. 15, p. 1-73.

Glikson, A.Y., 2001, The astronomical connection of terrestrial evolution: Crustal effects of post-3.8 Ga mega-impact clusters and evidence for major 3.2 $\pm 0.1 \mathrm{Ga}$ bombardment of the Earth-Moon system: Journal of Geodynamics, v. 32, p. 205-229.

Goleby, B.R., Korsch, R.J., Fomin, T., Bell, B., Nicoll, M.G., Drummond, B.J., and Owen, A.J., 2002, Preliminary 3-D geological model of the Kalgoorlie region, Western Australia, based on deep seismic reflection and potential field data: Australian Journal of Earth Sciences, v. 49, p. 917-933.

Hamilton, W.B., 2003, An alternative Earth: GSA Today, v. 13, no. 11, p. $4-12$.

Hamilton, P.J., Evensen, N.M., O'nions, R.K., Glikson, A.Y., and Hickman, A.H., 1981, Sm-Nd dating of the Talga-Talga Subgroup, Warrawoona Group, Pilbara Block, Western Australia. In: Archaean Geology, eds. J.E. Glover and D.I. Groves, Geological Society of Australia Special Publication, v. 7, p.187-192.

Kamber, B.S., Collerson, K.C., Moorbath, S., and Whitehouse, M.J., 2003, Inheritance of early Archaean $\mathrm{Pb}$ isotope variability from long-lived Hadean protocrust: Contributions to Mineralogy and Petrology, v. 145, p. 25-46.

Kröner, A., Byerly, G.R., and Lowe, D.R., 1991, Chronology of early Archaean granite-greenstone evolution in the Barberton Mountain Land, South Africa, based on precise dating by single zircon vaporation: Earth and Planetary Science Letters, v. 103, p. 41-54

Lowe, D.R., Byerly, G.R., Kyte, F.T., Shukolyukov, A., Asaro, F. and Krull, A., 2003, Spherule beds 3.47-3.34 Ga-old in the Barberton greenstone belt, South Africa: A record of large meteorite impacts and their influence on early crustal and biological evolution: Astrobiology, v. 3, p. 7-48

McCulloch, M.T., and Bennett, V.C., 1994, Progressive growth of the Earth's continental crust and depleted mantle: geochemical constraints: Geochimica et Cosmochimica Acta, v. 58, p. 4717-4738.

Ryder, G., 1990, Lunar samples, lunar accretion and the early bombardment of the Moon: Eos (Transactions, American Geophysical Union), v. 71, p. 313-322.

Simonson, B.M., Davies, D., Wallace, M., Reeves, S., and Hassler, S.W., 1998, Iridium anomaly but no shocked quartz from Late Archean microkrystite layer, oceanic impact ejecta?: Geology, v. 26, p. 195-198.

Van Kranendonk, M.J., Hickman, A.H., Smithies, R.S., and Nelson, D.R., 2002, Geology and tectonic evolution of the Archaean North Pilbara Terrain, Pilbara Craton, Western Australia: Economic Geology, v. 97, p. 695-732.

\section{An Alternative Earth: REPLY}

\author{
Warren B. Hamilton, \\ Department of Geophysics, Colorado School of Mines, Golden, \\ Colorado, 80401, USA
}

Andrew Glikson and I know from past discussions that we agree that plate tectonics did not operate within what are now Archean cratons during middle and late Archean time, and that we flatly disagree on my interpretation that voluminous, perhaps global, continental crust formed $>4 \mathrm{Ga}$. In my view, that protocrust remained too hot, and low in density, to permit surface eruption of mafic and ultramafic lavas until ca. $3.5 \mathrm{Ga}$, when the oldest "greenstone belt" rocks were erupted. Protocrust heat was added from beneath and was generated internally by, particularly, then-high ${ }^{235} \mathrm{U}$ and ${ }^{40} \mathrm{~K}$, and heat loss perhaps was minimized by a hot greenhouse atmosphere; nature of the surface is unknown, but there need have been neither water nor supracrustals other than crustal caps.

Can the scarcity of ancient zircons be reconciled with formation of voluminous continental crust before $4 \mathrm{Ga}$ ? Ancient zircons occur in place in polycyclic migmatites, and concordant zoned-zircon $\mathrm{U}-\mathrm{Pb}$ ages from them range far through Archean time from ancient maxima. There is little correlation between age increments in neighboring grains. The materials were repeatedly, or for long periods, at or near wet-granite solidus temperature. Zircon survival requires that all fluids in contact with the crystals throughout zircon-recorded time were saturated in $\mathrm{Zr}$, and hence that zircons survived only where reacting rock volumes never contained melts low in water or in $\mathrm{Al}_{2} \mathrm{O}_{3} /\left(\mathrm{Na}_{2} \mathrm{O}+\mathrm{K}_{2} \mathrm{O}\right)$ ratios, and may never have been into stability fields of garnet or hornblende, which accept Zr. Most Archean crust is exposed at shallow erosion levels, but most known ancient zircons are in middle crust raised, when cool, during Proterozoic and Phanerozoic time by basement thrusting or by shoulder uplift consequent on rifting (deformation lacking in Archean time). Depressurization of still-warm earlier Archean middle crust that rose as upper-crustal diapiric batholiths 3.5-2.5 Ga decreased water contents, and relict zircons were mostly destroyed.

Glikson argues that Archean tonalite-trondhjemite-granodiorite (TTG) formed by partial melting of hydrated mafic rocks in turn derived incrementally from near-solidus enriched upper mantle. I advocate this process for Phanerozoic arc magmatism (Hamilton, 1995), which deep-crustal exposures, compatible with seismic-velocity structure, show to typically produce thick underplated mafic complexes and widespread deep-crustal partial melting that left depleted mafic granulites. These features are lacking or minor in Archean crust, which is felsic and intermediate to the bottom and which overlies mantle profoundly depleted during Archean time (e.g., James and Fouch, 2002). A large-scale process is needed.

Petrology and chemistry of mantle xenoliths (Griffin et al., 2003) and $\mathrm{Sm}-\mathrm{Nd}$, U-Pb, and $\mathrm{Lu}-\mathrm{Hf}$ data from continental crust (e.g., Bizzarro et al., 2003; McCulloch and Bennett, 1994) show that upper mantle was depleted in crustal components very early in Earth's history, and has since been greatly re-enriched in them. This is in accord with early formation of voluminous crust and subsequent remixing into upper mantle that was effectively closed to introduction of material from lower mantle. The assumptions behind whole-rock $\mathrm{Rb}-\mathrm{Sr}$ rationales cited by Glikson against this conclusion-regional volumes had homogeneous initial $\mathrm{Rb}$ and $\mathrm{Sr}$ elemental and isotopic compositions, no variations record mixing lines, and even $\mathrm{Rb}$ was immobile during complex subsequent events-are invalidated by the common gross mismatches between ages calculated with those assumptions and concordant $\mathrm{U}-\mathrm{Pb}$ zircon ages

Glikson shows that Archean granite-and-greenstone ages are con- 
centrated in episodes. I presume such distributions to reflect variability of processes in time and space because of nonlinearity of variations of thermal diffusivity (Hofmeister, 2003), viscosity, and other properties with mantle temperature and pressure. Flow in the lower mantle, and transfer of heat from it to upper mantle, cannot be steady-state.

The "Late Heavy Bombardment" widely assumed to have affected the Moon ca. 3.9 Ga may not have happened, so no correlative catastrophic churning of terrestrial global lithosphere is required. Some lunar geologists (e.g., Haskin et al., 1998) argue that all dated shockmelted glasses of that age- the data cited by Glikson as evidence for a great barrage-came from the vast ejecta blanket from Imbrium basin. (Imbrium and Orientale, which is not directly dated, are the youngest mega-impact structures on the Moon.) The exponential decline of frequency of lunar ages of all sorts of rocks, including near-surface granophyres, that might be impact-lake fractionates (rather than products of endogenic magmatism as commonly assumed), from 4.4 to 3.9 $\mathrm{Ga}$ (e.g., Meyer et al., 1996), accord with $3.9 \mathrm{Ga}$ as marking the tail of main accretion of huge bolides. Only smaller masses (such as those for which Glikson notes evidence) that produced craters up to a few hundred kilometers in diameter have impacted since.

The only basement seen anywhere depositionally beneath Archean supracrustal rocks is polycyclic TTG. No Archean ophiolites are known, no Archean supracrustal rocks are proved ensimatic, and even ultramafic lavas widely show contamination by felsic crust. Older mafic supracrustals beneath younger are merely that and have nowhere been shown to overlie mantle rocks in either outcrop or subsurface. Thick felsic and intermediate crust, not mantle, lies beneath mafic supracrustals wherever seismic control is available. Thin quartzite and/or banded iron formation and chert were deposited directly on ancient-zircon gneisses, and on those strata in turn were erupted the mafic-volcanic sections, wherever the depositional bases of supracrustal sections are exposed (Bleeker, 2002). These strata and the overlying greenstones are mostly submarine: continental crust was submerged, so if sincevanished deep oceans did exist, freeboard considerations indicate their extent to have been small (Arndt, 1999). The notion that small ocean basins lay between microcontinents is poorly supported.

Long-continuing high-temperature ductility of deep Archean crust (not transport from distant sites) is shown by deformation such as that cited by Glikson and by the floating style of Archean upper-crustal tectonics. Megathrusting (as opposed to floating-crust jostling) during Archean time has often been conjectured but has nowhere been documented by careful mapping of dated assemblages.

\section{REFERENCES CITED}

Arndt, N., 1999, Why was flood volcanism on submerged continental platforms so common in the Precambrian?: Precambrian Research, v. 97, p. $155-164$.

Bizzarro, M., Baker, J.A., Haack, H., Ulfbeck, D, and Rosing, M., 2003, Early history of Earth's crust-mantle system inferred from hafnium isotopes in chondrites: Nature, v. 421, p. 931-933.

Bleeker, W., 2002, Archaean tectonics-a review, with illustrations from the Slave craton: Geological Society of London Special Publication 199, p. $151-181$.

Griffin, W.L., O’Reilly, S.Y., Abe, N., Aulbach, S., Davies, R.M., Pearson, N.J., Doyle, B.J., and Kivi, K., 2003, The origin and evolution of Archean lithospheric mantle: Precambrian Research, p. 19-41, doi:10.1016/S03019268(03)00180-3.

Hamilton, W.B., 1995, Subduction systems and magmatism: Geological Society of London Special Publication 71, p. 3-28.

Haskin, L.A., Korotev, R.L., Rockow, K.M., and Joliff, B.L., 1998, The case for an Imbrium origin of the Apollo thorium-rich impact-melt breccias: Meteoritics and Planetary Science, v. 33, p. 959-975.

Hofmeister, A.M., 2003, Could low thermal diffusivity provide runaway melting in the upper mantle?: Eos (Transactions, American Geophysical Union), v. 84 , no. 46 , suppl., p. F1542.

James, D.E., and Fouch, M.J., 2002, Formation and evolution of Archaean cratons-insights from southern Africa: Geological Society of London Special Publication 199, p. 1-26.

McCulloch, M.T., and Bennett, V.C., 1994, Progressive growth of the Earth's continental crust and depleted mantle-Geochemical constraints: Geochimica et Cosmochimica Acta, v. 58, p. 4717-4738.

Meyer, C., Williams, I.S., and Compston, W., 1996, Uranium-lead ages for lunar zircons-Evidence for a prolonged period of granophyre formation from 4.32 to 3.88 Ga: Meteoritics and Planetary Science, v. 31, p. 370-387.

Wolfe, C.J., Bjarnason, I.T., VanDecar, J.C., and Solomon, S.C., 2002, Assessing the depth resolution of tomographic models of upper mantle structure beneath Iceland: Geophysical Research Letters, v. 29, no. 2, paper 2, 4 p. 